\title{
Development of Labrus Bergylta (Ascanius 1767) Larvae from Hatching to Metamorphosis
}

\section{OH Ottesen ${ }^{1, *}$, E Dunaevskaya ${ }^{1}$ and JD'Arcy²}

${ }^{1}$ University of Nordland, Faculty of Biosciences and Aquaculture, 8049 Bodø, Norway

${ }^{2}$ MRI Carna, Ryan Institute for Environment, Marine \& Energy, National University of Ireland, Galway, Ireland

\begin{abstract}
Ballan wrasse, Labrus bergylta (Ascanius, 1767), has commercial interest as a cleaner fish in aquaculture, and culture of juveniles may be a good alternative to catching wild fish. However, basic knowledge of early development is limited. To study hatching and larvae ontogenesis, eggs were collected from a broodstock of wild caught ballan wrasse held in captivity. Larvae were fed rotifers for 27 days; Artemia was introduced at day 20 and fed larvae to day 49 after hatching. Age at hatching, and larval ontogenesis based on external morphological features were linked to the chronological age of larvae as days post hatching (DPH) and physiological age as degree day $\left({ }^{\circ} \mathrm{C}\right.$.day) and standard length (SL). The ballan wrasse egg diameter was $1.05 \pm 0.04 \mathrm{~mm}$ and $0.87 \pm 0.05 \mathrm{~mm}$ with and without the gelatinous layer, respectively, and hatched at a SL of $3.64 \pm 0.05 \mathrm{~mm}, 7$ days, i.e., $72^{\circ} \mathrm{C}$.day, after fertilization. The ontogeny of larvae from hatching to metamorphosis was divided into four stages. Yolk sac larva, 0 to $9 \mathrm{DPH}$ (SL 4.28 $\pm 0.11 \mathrm{~mm}$ ), where mouth opens and pigmentation of the eyes is seen. Dilated swim bladder is visible. Preflexion larva, 10 to $25 \mathrm{DPH}$ (SL $5.35 \pm 0.30 \mathrm{~mm}$ ); yolk sac has disappeared, and initial formation of caudal fin rays occurs. Gaseous inflation of swim bladder is observed. Flexion larva, 26 to $33 \mathrm{DPH}$ (SL $5.9 \pm 0.78 \mathrm{~mm}$ ), initial resorption of primordial fin fold is seen. Postflexion larva, 34 to $49 \mathrm{DPH}$ (SL $10.52 \pm 0.82 \mathrm{~mm}$ ) by the end of this stage (age $686^{\circ} \mathrm{C}$.day), the dorsal, anal, caudal and pelvic fins were developed. The ontogenetic development, linked to SL, chronological and physiological age, provides a baseline reference and makes it possible to compare developmental levels in future studies of ballan wrasse in culture and wild populations.
\end{abstract}

Keywords: Cleaner fish; Ontogeny; Larviculture; Fish morphology; Swim bladder

\section{Introduction}

In European aquaculture the development of resistance in the ectoparasite Lepeophtheirus salmonis (Krøyer), to chemotherapeutic treatment [1] cause negative attention, influence the economic outcome [2] and threatens the liability and sustainability of salmon industry.

Ballan wrasse, Labrus bergylta (Ascanius, 1767), has recently attracted commercial interest as a cleaner fish in aquacultural systems. Ballan is the largest of the north European wrasses, and may reach a total length of $65.9 \mathrm{~cm}, 4.35 \mathrm{~kg}$ and 29 years of age [3]. However, there is growing concern that fishing pressure on populations of ballan wrasse for stocking in salmon sea cages may result in depletion and overexploitation, and that the fishery is not sustainable. Thus, juvenile cultures of ballan wrasse may be a good alternative to catching wild fish for stocking in sea cages. However, protocols for egg and juvenile culture have not been developed, commercial production is still in the experimental period and is minimal, and several bottlenecks have to be overcome to achieve large scale production of this species. However, there is large interest in cultivation and application of ballan wrasse, and a rapid increase in investment and in hatchery capability. A detailed understanding of larval development is necessary to establish efficient hatchery technology and protocols.

The eggs of ballan wrasse are spherical, about $1 \mathrm{~mm}$ in diameter, and hatching takes place when the larva is approximately $3 \mathrm{~mm}$ in length [4]. The ontogenesis of fish larvae may be divided into different stages: yolk sac, preflexion, flexion, postflexion stages and metamorphosis, based on major developmental events [5]. Preliminary studies have shown that in ballan wrasse preflexion larvae are partially pigmented on the body, while there is no pigmentation in the caudal region, on the snout or on the lower jaw [6]. The flexion stage is characterized by the possession of an inter-spineous area of the caudal fin. The urochord is fully bent upwards and melanophores appear anteriorly on the anal fin when the larva is approximately $8 \mathrm{~mm}$ in length [7]. In many species, the swim bladder, which acts as a hydrostatic organ, is filled after hatching. For example, in cod, Gadus morhua L., it is developed at $10 \mathrm{DPH}$ [8], whereas, in other species, this may take several weeks or months [9]. This event occurs within certain intervals during early development, often associated with the transition from endogenous to exogenous feeding in larvae [10]. Successful inflation of the swim bladder during early development is vital for manoeuvring ability, feeding success and larval survival [11].

The chronological age of the larva does not necessarily indicate its physiological age, which depends mainly on water temperature [5]. Thus, staging of larval ontogenesis based on external morphological features should be related to their age given as days and as day-degrees, i.e. their chronological and physiological age, respectively, and linked to standard length. There are only a few sources of information on wrasse larval development, especially on ballan wrasse. Artuz [12] studied gross morphology in ballan wrasse and described some features of larvae ontogeny. However, information on chronological or physiological age was not provided. Thus, it is difficult to compare developmental

*Corresponding author: $\mathrm{OH}$ Ottesen, University of Nordland, Faculty of Biosciences and Aquaculture, 8049 Bodø, Norway, Tel. +47 75517485; Fax: +47 755 17410; E-mail: oddvar.ottesen@uin.no

Received March 16, 2012; Accepted March 24, 2012; Published March 30, 2012

Citation: Ottesen OH, Dunaevskaya E, Arcy JD (2012) Development of Labrus Bergylta (Ascanius 1767) Larvae from Hatching to Metamorphosis. J Aquac Res Development 3:127 doi:10.4172/2155-9546.1000127

Copyright: (c) 2012 Ottesen $\mathrm{OH}$, et al. This is an open-access article distributed under the terms of the Creative Commons Attribution License, which permits unrestricted use, distribution, and reproduction in any medium, provided the original author and source are credited. 
levels in future studies of ballan wrasse in aquaculture and natural populations because of the absence of a common scheme that includes the age of larvae. The main objective of the present work was to classify the sequence of developmental events in ballan wrasse ontogeny from hatching to metamorphosis when eggs and larvae were cultured under a controlled environment.

\section{Materials and Methods}

\section{Broodstock and egg production}

Ballan wrasse eggs were collected in July 2009 from a broodstock kept at University of Nordland, Mørkvedbukta Research Station, Norway. The broodstock consisted of wild-caught fish held indoor in two black circular (5000 l) fibreglass tanks, each with one male and $15 \mathrm{fe}$ males. The broodstock were kept under artificial light and with natural photoperiod conditions. The seawater temperature was $7.7 \pm 0.2^{\circ} \mathrm{C}, \mathrm{n}$ $=115$ during the period from 1 August of the previous year to $30 \mathrm{May}$, and increased gradually to $9 \pm 1.2^{\circ} \mathrm{C}$ in June and further to $11 \pm 0.3^{\circ} \mathrm{C}$ by the end of July. Salinity was stable and oxygen level was held above $8.3 \mathrm{mg} . \mathrm{L}^{-1}$ by regulating the inlet water flow. The fish were fed to satiation three times per week with feed composing $7.5 \mathrm{~kg}$ whole shrimps, 5 $\mathrm{kg}$ premix dry feed (Fish Breed M. INVE, Belgium) and $100 \mathrm{ml}$ fish oil (Omega Standard, Denomega Nutritional Oils AS, Leknes, Norway).

The tanks were equipped with shelters such as pieces of plastic pipes (length $30-50 \mathrm{~cm}$, diameter $90-110 \mathrm{~mm}$ ), and artificial seaweed made from black plastic bags. Eggs were spawned transparent plexiglass plates, size $20 \times 50 \mathrm{~cm}$ distributed at the bottom of the tank.

The tanks were inspected daily during the spawning season. Spawning usually occurred in the morning, between 0900 and $1100 \mathrm{~h}$. Eggs were checked for fertilization ratio when collected from the tanks. Plates with fertilized eggs were transferred to 280 L.volume incubators and incubated in darkness. Temperature was held at $11^{\circ} \mathrm{C}$, salinity was $34 \%$ and the water flow rate was 3 L.min ${ }^{-1}$. Seawater was passed through a $10-\mu \mathrm{m}$ filter and a protein skimmer, ozonated and degassed using a vacuum degasser.

\section{Startfeeding and tank environment}

For startfeeding, newly hatched larvae originating from two separate spawnings in two broodstock tanks were transferred to black polyethylene tanks, Tank 1 and Tank 2, each with a volume of $80 \mathrm{~L}$.

The flow rate of seawater was $200 \mathrm{ml} \cdot \mathrm{min}^{-1}$ and was gradually increased to $600 \mathrm{ml} \cdot \mathrm{min}^{-1}$ at day 7. Larvae were stocked at a density of ca. 60 larvae. $\mathrm{L}^{-1}$ in the tanks. Larval culture was carried out under artificial low energy light provided by one $36 \mathrm{~W}$ lamp (Goliath, 2850 lumen, www.wuerth.no) situated $50 \mathrm{~cm}$ above each tank with a photoperiod of $18 \mathrm{~h}$ light (1100 lux) and $6 \mathrm{~h}$ total darkness. Air was supplied from the bottom creating a gentle upwelling in the centre of the tank. The water temperature was gradually increased from 11 to $14^{\circ} \mathrm{C}$ over 4 days, with an average temperature $\left({ }^{\circ} \mathrm{C}\right)$ of $11.83 \pm 1.13 ; 0-6 \mathrm{DPH}, 13.83 \pm 0.15 ; 7-9$ $\mathrm{DPH}, 14.26 \pm 0.14 ; 10-25 \mathrm{DPH}, 14.46 \pm 0.07 ; 26-33 \mathrm{DPH}, 14.33 \pm 0.08$; 34-49 DPH.

Seawater for startfeeding tanks was passed through a 6- $\mu \mathrm{m}$ filter and treated as described above. Water surface film of the tanks was removed daily using paper towels.

Larvae were fed cultured rotifers, Brachionus plicatilis, at a concentration of 5-7 rotifers $\mathrm{ml}^{-1}$, enriched with Red Pepper (Bernaqua NV Hagelberg 3 B-2250 Olen Belgium) from 4 days post hatching, once a day, increased to three times per day from day 7. Algae (Chlorella sp.;
Pacific Trading Co., Ltd. Fukuoka, Japan) were added to the rotifers (20 $\mathrm{ml} .8 \mathrm{~L}^{-1}$ of rotifers) before they were added the tanks. To establish greenwater, algae paste (10-15 ml.tank ${ }^{-1}$. day $\left.{ }^{-1}\right)$ consisting of Nannochloropsis spp. (Nanno 3600, Reed Mariculture Inc, USA) was used according to the manufacturer's guidelines: diluted 1:10 in seawater and gently poured into the tanks every day at $1000 \mathrm{~h}$. Artemia sp. (1 individual $\mathrm{ml}^{-1}$ ) enriched with Red Pepper, were introduced at $20 \mathrm{DPH}$. Rotifers were given until day 27, i.e. co-feeding was performed for 7 days.

\section{Sampling}

The diameter of eggs sampled one day after fertilization was measured, and $50 \%$ hatching occurred around $72^{\circ} \mathrm{C}$.day $\left(6.6\right.$ days at $\left.11^{\circ} \mathrm{C}\right)$.

Larvae were sampled from startfeeding Tanks 1 and 2, anaesthetized in $70 \mathrm{mg} . \mathrm{L}^{-1}$ tricaine methanesulfonate (MS-222, Sigma). From Tank 15 larvae were sampled daily between 0 and $9 \mathrm{DPH}$ and every $4^{\text {th }}$ day between 9 and 49 DPH. From Tank 2 five larvae were sampled every $2^{\text {nd }}$ day from $6 \mathrm{DPH}$ to $17 \mathrm{DPH}$. Sampling data, age as DPH and ${ }^{\circ} \mathrm{C}$.day $(\mathrm{DPH} \times$ temperature) were noted for each sample. Larvae were fixed in a mixture of $10 \%$ paraformaldehyde and $25 \%$ glutaraldehyde in cacodylate buffer ( $\mathrm{pH}$ 7.2).

\section{Eggs and larvae development}

Eggs, and larvae from Tank 1 and Tank 2 were viewed and photographed using a stereomicroscope with a digital camera (Olympus, Tokyo, Japan), using Cell^A software (Olympus, Tokyo, Japan) for morphometric studies. Drawings were made of larvae at different stages based on images using Adobe Photoshop CS5. Descriptions of pigmentation of newly hatched, yolk sac and on-growing larvae were made with reference to different body regions. Timing the occurrence of larvae with dilated swimbladder, and with reflective gas present in swimbladder was conducted on fixated larvae from Tank 1 and 2. The stage of larval ontogenesis was assessed on the basis of standard length and the main external morphological features, which are related to age, given as $\mathrm{DPH}$ and as ${ }^{\circ} \mathrm{C}$.day.

The diameter of eggs was measured, with and without the gelatinous layer, and values are given as average \pm standard deviation (SD) and the number of eggs measured. From Tank 1, standard length (SL) of five larvae sampled at $0,9,17,25,33$ and $49 \mathrm{DPH}$ was measured from the tip of the snout to the end of notochord for preflexion larva, or to the end of the vertebral column after flexion to the nearest $0.01 \mathrm{~mm}$ on each sampling day.

\section{Results}

\section{Egg size and larval development}

Ballan wrasse egg diameter was $1.05 \pm 0.04 \mathrm{~mm}, \mathrm{n}=24$ and 0.87 $\pm 0.05 \mathrm{~mm}, \mathrm{n}=24$, with and without the gelatinous layer, respectively. Newly hatched larvae measured $3.64 \pm 0.05 \mathrm{~mm}$ and had reached 10.52 $\pm 0.82 \mathrm{~mm}$ by $49 \mathrm{DPH}$.

\section{Development of larvae}

Four main age-related stages were identified during ballan wrasse larval development on the basis of external morphological features and structural changes (Table 1).

Stage 1. Yolk sac larva: This stage started when the larva hatched. The embryo freed itself from the egg membrane with rapid movements of the body and tail. The newly hatched larva (Figure 1) was transparent and floated at the surface with the ovoid unsegmented yolk sac uppermost and sometimes in a lateral position. The head was pointed 


\begin{tabular}{|l|l|l|l|l|l|}
\hline Stage & $\begin{array}{l}\text { Developmental } \\
\text { stage }\end{array}$ & DPH & SL & ${ }^{\circ}$ C.day & Food source \\
\hline 1 & Yolk sac larva & $0-9$ & $4.28 \pm 0.11$ & $0-108$ & $\begin{array}{l}\text { endo- and } \\
\text { exogenous }\end{array}$ \\
\hline 2 & Preflexion larva & $10-25$ & $5.35 \pm 0.30$ & $122.1-340.7$ & exogenous \\
\hline 3 & Flexion larva & $26-33$ & $5.90 \pm 0.78$ & $355-456.4$ & exogenous \\
\hline 4 & Postflexion larva & $34-49$ & $10.52 \pm 0.82$ & $470.8-685.7$ & exogenous \\
\hline
\end{tabular}

Table 1: Main developmental stages of ballan wrasse larvae based on external morphological observations. All stages are related to age as days post hatching $(\mathrm{DPH})$, mean standard length $(\mathrm{SL})$ in $\mathrm{mm} \pm$ standard deviation of larvae $(n=5)$ at the end of each stage, degree days $\left({ }^{\circ} \mathrm{C}\right.$.day), and food source.

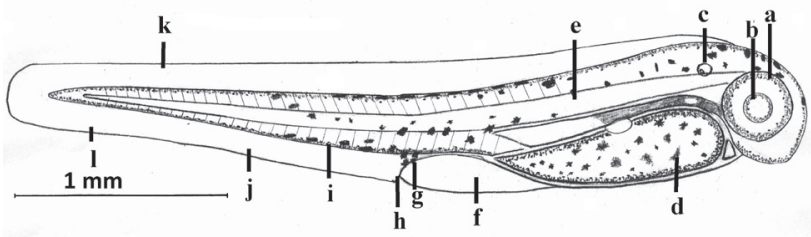

Figure 1: Ballan wrasse larva $0 \mathrm{DPH}, 3.64 \pm 0.05 \mathrm{~mm} \mathrm{SL}$. a, eye; b, lens; c, otic capsule; d, yolk sac; e, notochord; f, preanal fin fold; g, gut; h, urinary bladder; i, myotome; j, postanal part of the fin fold; k, dorsal part of the fin fold; I, caudal part of the fin fold.

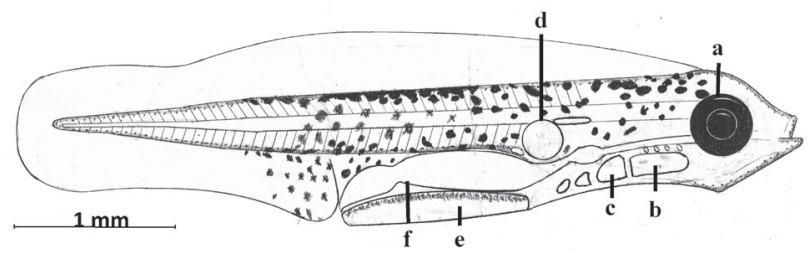

Figure 2: Ballan wrasse larva, $13 \mathrm{DPH}\left(160^{\circ} \mathrm{C}\right.$.day $), 4.78 \pm 0.19 \mathrm{~mm}$. a, pigmented eye; b, heart; c, liver; $d$, inflated swim bladder; e, remnants of yolk sac; $f$, gut.

forwards and partly free from the yolk sac and the mouth was undeveloped. The fin-fold compromised much of the body and was subdivided into a pre-anal fold, dorsal, caudal and post-anal parts. A total of 48 somites were recorded. The larvae body was pigmented with melanophores from the head to approximately the eight post-anal segment. The eyes were not pigmented and were presumed to be non-functional. Otic capsules were observed. At $3 \mathrm{DPH}$, the yolk sac became smaller and dorsal swimming activities increased. Pigmentation had increased on the yolk sac and body, and black pigmentation was distinguishable in the eyes. By $6 \mathrm{DPH}$, the black pigmentation in the eyes had increased and the mouth had begun to open. The body and notochord were straight.

The eyes were completely pigmented at $7 \mathrm{DPH}$ and became functional, allowing the larva to search and orientate on food particles. The mouth was now fully open and functional, and the larvae were ready for exogenous feeding. A small yolk sac was still present, so larvae were not totally dependent on external nutrients. Initial pigmentation of the ventral gut and postanal fin regions of the finfold was visible. The time of the first exogenous feeding was noted and the passage of food along the digestive tract and rotifers in the stomach of the larvae were clearly visible. The larva still had some yolk remaining up to $9 \mathrm{DPH}$. The spherical swim bladder was dilated at day 7. Melanophores were concentrated on the nape, crown, isthmus regions and the trunk. The ventral gut region and a third of the anal fin region were also pigmented.

Stage 2. Preflexion larva: The yolk sac had disappeared by $10 \mathrm{DPH}$. The first observation of inflated swim bladder was at $13 \mathrm{DPH}$ (Figure 2). Further observations of larvae with inflated swim bladder were at 16
$\mathrm{DPH}$ and $17 \mathrm{DPH}$. The swim bladder anlage is attached to the dorsal part of the front midgut. At $25 \mathrm{DPH}$, the caudal fin rays anlage appeared. The head, body and fins were heavily pigmented. Melanophores were concentrated on two-thirds of the anal fin region.

Stage 3. Flexion larva: The upward inclination of the posterior part of urostyle could be observed (Figure 3). Initial resorption of primordial fin fold was seen, and at $29 \mathrm{DPH}$, small pelvic fins were visible. Towards the end of this stage the caudal fin starts to separate from the dorsal fin as a discontinuity in the margin of the finfold. The anlage of the dorsal fin and the incipient rays of the anal fin were visible.

Stage 4. Postflexion larva: By $37 \mathrm{DPH}$, caudal, dorsal and anal fins were separated. The anal fin was pigmented and body pigmentation had also spread to the end of anal fin. All fin rays were formed (Figure 4). By the end of this stage, dorsal, anal, caudal and pelvic fins were developed and the larval body was fully pigmented, except the urostyle region (Figure 5).

\section{Discussion}

This report gives for the first time morphological features of cultured ballan wrasse larvae linked to standard length, chronological and physiological age. Ballan wrasse larvae were $3.64 \pm 0.05 \mathrm{~mm} \mathrm{SL}$ at hatching, comparable to larvae size (TL $3.9 \mathrm{~mm}$ ) observed in an Irish study [4]. This is much larger than reported for ballan wrasse previously [12], where a standard length of $2.7 \pm 0.2 \mathrm{~mm}$ at hatching was recorded. The length of newly hatched larvae of ballan wrasse in the present study was significantly larger than reported in many other labrid species [13], although similar to brown wrasse Labrus merula L. [14]. The variation in size of ballan wrasse larvae at hatching may be linked to egg diameter, which has a relatively large natural variation, ranging from 0.7 $\mathrm{mm}$ [7] to $1.14 \mathrm{~mm}$ [15], compared with $1.05 \pm 0.04 \mathrm{~mm}$ in the present study. Larger eggs produce larger fry [16] and maternal effects on egg size, and thus on larval size, may be large [17].

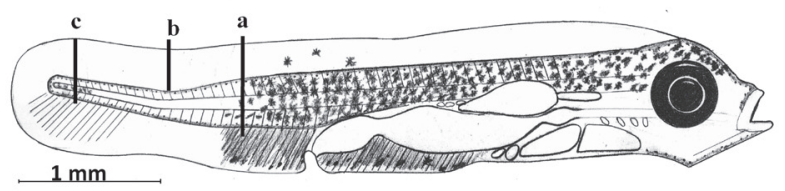

Figure 3: Ballan wrasse larva $29 \mathrm{DPH}\left(396^{\circ} \mathrm{C}\right.$.day), $5.40 \pm 0.66 \mathrm{~mm} \mathrm{SL}$. a, incipient rays of anal fin; $b$, inclination of urostyle; $c$, caudal fin rays anlage.

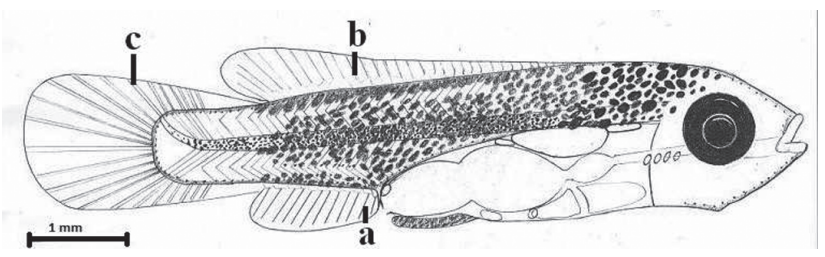

Figure 4: Ballan wrasse larva $37 \mathrm{DPH}\left(512^{\circ} \mathrm{C}\right.$.day), $7.90 \pm 0.41 \mathrm{~mm} \mathrm{SL}$.; a, anal fin; b, dorsal fin; c, caudal fin.

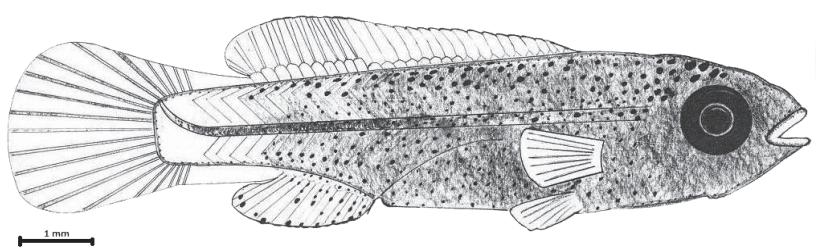

Figure 5: Ballan wrasse larva $49 \mathrm{DPH}\left(686^{\circ} \mathrm{C}\right.$.day), $10.52 \pm 0.82 \mathrm{~mm} \mathrm{SL}$. 
It is recognized that the period when several essential organs are being developed, is critical in the larviculture of many marine species $[5,18]$. Whether this is the case in ballan wrasse is not known, but high mortality during early stages indicate that larvae in stages 1 and 2 may be vulnerable as new structural elements were observed during these stages, whereas stage 3 and 4 was characterized by quantitative changes in already established structures.

The gross morphological developmental characteristics of ballan wrasse larvae were divided into four ontogenetic stages. Comparable staging based on food source and gross morphological characteristics has been reported in gilthead sea bream [19] and in brill [20], respectively. In histological sections of ballan wrasse larvae, primordial swim bladder appeared at $4 \mathrm{DPH}$, the pneumatic duct was visible and gas gland appeared at $7 \mathrm{DPH}$ [21]. The first observations of larvae with dilated swimbladder were $7 \mathrm{DPH}$, whereas larvae with inflated swim bladder was first observed at $13 \mathrm{DPH}$ and last time observed at $17 \mathrm{DPH}$. Thus, the first observations of swim bladder inflation in ballan wrasse larvae in the present study were at an earlier development stage and in smaller larvae (SL $4.8 \mathrm{~mm}$ ) as compared to observations of Artuz [12]. The exact time, or time interval, at which the pneumatic duct closes, and therefore the duration of the window for swim bladder inflation, has not yet been histologically confirmed [21]. This evidence for intra-cohort variation in swim bladder inflation is in agreement with observations in other species, e.g. in brill larvae [20], inflation occurred during an interval of 3 days, in common dentex the interval was 2 days [18], whereas in striped trumpeter, Latris lineate, the swim bladder inflation interval was 5 days (8-12 DPH) [22]. In some cases larvae with ingested rotifers, but without inflated swim bladders, were observed. In cod larvae, an inflated swim bladder is visible at $5 \mathrm{DPH}$, while the first feed intake is around 3-4 DPH $[23,24]$. Most likely there is an inter- and intra-cohort variations in first feed intake and swim bladder inflation in ballan wrasse, as seen in many other species.

The ontogenetic development of ballan wrasse linked to standard length, chronological and physiological age provides a baseline reference that will make it possible to compare developmental levels in future studies of ballan wrasse in culture and wild populations.

\section{Acknowledgements}

We are grateful for the technical assistance received from Jacek Perkowsk and the staff at University of Nordland, Mørkvedbukta Research Station. This research was partly funded EU structural funds and Northern Periphery Programme through the project EcoFish (No 304-9075-2009).

\section{References}

1. Rombough PJ (1988) Respiratory gas exchange, aerobic metabolism, and effects of hypoxia during early life. In: Fish physiology 11A: 59-161 Hoar WS, Randall DJ, Farrell AP (Eds.) Academic Press, New York.

2. Pike AW, Wadsworth SL (1999) Sealice on Salmonids: Their Biology and Control. Adv Parasitol 44: 233-237.

3. Labrus bergylta Ascanius, 1767 Ballan wrasse, http://fishbase.org/summary/ Labrus-bergylta.html

4. D’Arcy J, Dunaevskaya E, Treasurer J, Ottesen O, Maguire J, et al. (2011) Embryonic development of Ballan Wrasse, Labrus bergylta L. Journal of Fish Biology. In press

5. Blaxter JHS (1988) Pattern and variety in development. In: Fish physiology, Vol. Fish physiology XI. The physiology of developing fish. Hoar WS, Randall DJ (Eds.) Academic Press, New York.

6. Fives JM (1976) Labridae of the eastern North Atlantic. In: Identification sheets on fish eggs and larvae. Fraser JH, Fives JM (Eds.) Conseil International pour l'Exploration de la Mer, Danemark.
7. Munk P, Nielsen JG (2005) Eggs and larvae of North Sea fishes. Biofolia, Frederiksberg. J Plankton Res 28: 533.

8. Morrison CM (1993) Histology of Atlantic cod Gadus morhua: an Atlas. Part Four. Eleutheroembryo and Larva. Canadian Special Publication of Fisheries and Aquatic Sciences 119: 1-499.

9. Falk-Petersen IB (2005) Comparative organ differentiation during early life stages of marine fish. Fish Shellfish Immunol 19: 397-412.

10. Trotter AJ, Pankhurst PM, Battaglene SC (2005) A finite interval of initial swimbladder inflation in Latris lineata revealed by sequential removal of water-surface films. J Fish Biol 67: 730-741.

11. Woolley LD, Qin JG (2010) Swimbladder inflation and its implication to the culture of marine finfish larvae. Reviews in Aquaculture 2: 181-190.

12. Artuz ML (2005) Embryonic and larval development of the ballan wrasse Labrus bergylta Ascanius 1767. Hidrobiologica 10: 98-101.

13. Kimura S, Nakayama Y, Kiriyama T (1998) Comparison of laboratory-reared eggs, embryos and larvae of five labrid fishes. Environ Biol Fishes 52: 187-201.

14. Dulcic J, Kozul V, Kraljevic M, Skaramuca B, Glamuzina B, et al. (1999) Embryonic and larval development of the brown wrasse Labrus merula (Pisces: Labridae). J Mar Biol Assoc U K 79: 327-332.

15. Ehrenbaum E (1905) Eier und Larven von Fischen. Nordisches Plankton 1 $1-413$.

16. Bromage N, Jones J, Randall C, Thrush M, Davies B, et al. (1992) Broodstock management, fecundity, egg quality and the timing of egg-production in the rainbow trout (Oncorhynchus mykiss). Aquaculture 100: 141-166.

17. Chambers RC, Leggett WC (1996) Maternal influences on variation in egg sizes in temperate marine fishes. Amer Zool 36: 180-196.

18. Santamaría CA, Marín de Mateo M, Traveset R, Sala R, Grau A, et al. (2004) Larval organogenesis in common dentex Dentex dentex L. (Sparidae): histological and histochemical aspects. Aquaculture 237: 207-228

19. Elbal MT, García Hernández MP, Lozano MT, Agulleiro B (2004) Development of the digestive tract of gilthead sea bream (Sparus aurata L.). Light and electron microscopic studies. Aquaculture 234: 215-238.

20. Hacherocruzado I, Ortizdelgado J, Borrega B, Herrera M, Navas J, et al. (2009) Larval organogenesis of flatfish brill Scophthalmus rhombus L: Histological and histochemical aspects. Aquaculture 286: 138-149.

21. Dunaevskaya $E$, Amin $A B$, Ottesen $O H$ (2011) Histological investigations of organs and tissues during organogenesis of ballan wrasse, Labrus bergylta larvae Submitted.

22. Battaglene SC, Cobcroft JM (2007) Advances in the culture of striped trumpeter larvae: A review. Aquaculture 268: 195-208.

23. Brown JA, Minkoff G, Puvanendran V (2003) Larviculture of Atlantic cod (Gadus morhua): progress, protocols and problems. Aquaculture 227: 357-372.

24. Rosenlund G, Halldórsson Ó (2007) Cod juvenile production: Research and commercial developments. Aquaculture 268: 188-194. 